\title{
Efektifitas Mediasi Terhadap Perkara Perceraian Di Pengadilan Agama Kelas ra Watampone
}

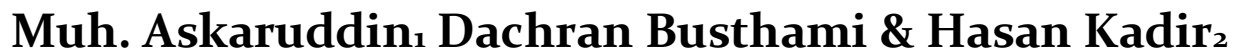 \\ ıMagister Ilmu Hukum, Universitas Muslim Indonesia, Indonesia \\ 2Fakultas Hukum, Universitas Muslim Indonesia \\ Koresponden: Email: askar_acho@yahoo.com
}

\begin{abstract}
ABSTRAK
Tujuan penelitian mengungkap efektivitas mediasi dalam perkara perceraian di Pengadilan Agama Kelas 1A Watampone. Berdasarkan hasil analisa efektivitas mediasi dalam perkara perceraian di Pengadilan Agama Kelas ıA Watampone, menunjukan bahwa mediasi belum efektif. Faktor-faktor penyebabnya adalah: Tingkat kepatuhan masyarakat yang menjalani proses mediasi sangat rendah. Fasilitas dan sarana mediasi di Pengadilan Agama Kelas 1A Watampone masih kurang memadai baik dari segi ruang mediasi maupun fasilitas penunjang didalamnya. Selain Ketua Pengadilan Agama Kelas 1A Watampone, hakim yang ditunjuk menjadi mediator seluruhnya belum mengikuti pelatihan mediasi yang diselenggrakan oleh Mahkamah Agung Republik Indonesia. Penempatan pelaksanaan mediasi di Pengadilan Agama tidak tepat atau tidak sesuai dengan apa yang telah digariskan oleh Allah swt., dalam QS al-Nisa>'/4: 35, tentang kedudukan dan kewenangan hakam (mediator) dalam menyelesaikan konflik yang terjadi dalam rumah tangga.
\end{abstract}

Kata Kunci: Mediasi; Perceraian; Pengadilan Agama

\section{ABSTRACT}

The purpose of the study revealed the mediation method in divorce cases in the Class 1 A Religious Court of Watampone. Based on the results of the analysis of mediation in divorce cases in Watampone Class ${ }_{1} A$ Religious Courts, it shows that mediation has not been effective. The contributing factors are: The level of community participation that supports the mediation process is very low. Mediation facilities and facilities in the Class 1 A Religious Court of Watampone are still inadequate in terms of mediation space and supporting facilities therein. In addition to the Chairperson of Class 1 A Religious Court Watampone, the judge appointed to be a mediator had fully received mediation training conducted by the Supreme Court of the Republic of Indonesia. Placement of mediation in the Religious Courts is not right or not in accordance with what has been outlined by God Almighty.

Keywords: Mediation; Divorce; religious courts 


\section{PENDAHULUAN}

Sebagai metode penyelesaian sengketa secara damai, mediasi mempunyai peluang yang besar untuk berkembang di Indonesia (Saladin, 2017). Dengan adat ketimuran yang masih mengakar, masyarakat lebih mmengutamakan tetap terjalinnya hubungan silaturrahmi antar keluarga atau hubungan dengan rekan bisnis daripada keuntungan sesaat apabila timbul sengketa (Tamalawe, 2016). Menyelesaikan sengketa di Pengadilan mungkin menghasilkan keuntungan besar apabila menang, namun hubungan juga menjadi rusak. Menyelamatkan muka (Face saving) atau nama baik seseorang adalah hal penting yang kadang lebih utama dalam proses penyelesaian sengketa di Negara berbudaya Timur, termasuk Indonesia (Lestari, 2013).

Mediasi merupakan alternatif penyelesaian sengketa atau biasa dikenal dengan istilah “alternative dispute resolution” yang tumbuh pertama kali di Amerika Serikat. Mediasi ini lahir dilatarbelakangi oleh lambannya proses penyelesaian sengketa di Pengadilan (Korah, 2013). Oleh karena itu mediasi ini muncul sebagai jawaban atas ketidakpuasan yang berkembang pada sistem peradilan yang bermuara pada persoalan waktu, biaya dan kemampuannya dalam menangani kasus yang kompleks (Komarudin, 2014). Padahal di Nusantara telah lama dipraktekkan tentang penyelesaian sengketa melalui musyawarah. Istilah khusus dalam pengadilan disebut mediasi.

Mediasi sangat sulit diberi pengertian. Dimensinya sangat jamak dan tak terbatas. Sehingga banyak orang yang menyebutkan mediasi tidak mudah diberi defenisi. "Mediation is not easy to definite". Hal ini karena mediasi tidak memberi satu model yang dapat diuraikan secara terperinci dan dibedakan dari proses pengambilan keputusan lainnya (Nurhadi, 2014). Mediasi sangat tergantung pada lakon yang dimainkan oleh pihak yang terlibat dalam penyelesaian masalah. Pihak yang terlibat adalah pihak mediator dan pihak yang tersangkut dalam sengketa.

Dalam Peraturan Mahkamah Agung No. 1 tahun 2008, pengertian mediasi disebutkan dalam Pasal 1 butir 6, yaitu: "Mediasi adalah penyelesaian sengketa melalui proses perundingan para pihak dengan dibantu oleh mediator". Disini disebutkan kata mediator, yang harus mencari "berbagai kemungkinan penyelesaian sengketa" yang diterima para pihak. Pengertian mediator, disebutkan dalam Pasal 1 butir 5, yaitu: "Mediator adalah pihak yang bersifat netral dan tidak memihak, yang berfungsi membatu para pihak dalam mencari berbagai kemungkinan penyelesaian sengketa”. Para pihak akan mengambil keputusan sendiri atas dasar negosiasi dengan pihak lawannya (Handayani \& Syafliwar, 2017).

Mediasi di Pengadilan Agama adalah suatu proses usaha perdamaian antara suami dan isteri yang telah mengajukan gugatan cerai, dimana mediasi ini dijembatani oleh seorang Hakim yang ditunjuk di Pengadilan Agama (Salamah, 2013). Dalam kasus perkara perceraian sangat dianjurkan melakukan mediasi. Bahkan satu-satunya sengketa dalam Islam yang disebut langsung penyelesaiannya diutamakan melalui mediasi. Allah SWT Berfirman dalam Surah An-Nisaa/4: 35: 


\section{عَلِيمًا خَبِيرًا

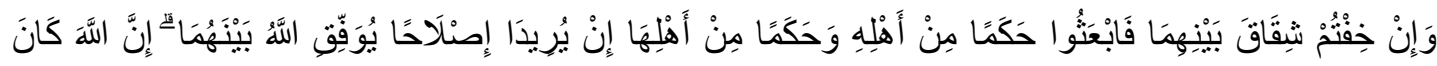

Terjemahannya:

Dan jika kamu khawatirkan ada persengketaan antara keduanya, maka kirimlah seorang hakam dari keluarga laki-laki dan seorang hakam dari keluarga perempuan. Jika kedua orang hakam itu bermaksud mengadakan perbaikan, niscaya Allah memberi taufik kepada suami-istri itu. Sesungguhnya Allah maha mengetahui lagi maha mengenal.

Salah satu sebab dimungkinkannya perceraian tersebut adalah syiqaq (terjadinya perselisihan atau persengketaan yang berlarut-larut antara suami isteri) (Abbas, et.al, 2018). Namun jauh sebelumnya dalam al-Qur'an sebagaimana di sebutkan dalam firmanNya diatas, Allah SWT, telah memerintahkan bahwa jika dikhawatirkan ada persengketaan antara keduanya ( suami istri), maka kirimkanlah seorang hakam (mediator) dari keluarga laki -laki dan seorang mediator dari keluarga perempuan. Dari ayat tersebut, dapat dipahami bahwa salah satu cara menyelesaikan perselisihan atau persengkataan anatara suami istri, yaitu dengan jalan mengirim seorang hakam "Mediator": dari kedua belah pihak untuk membantu menyelesaikan perselisihan tersebut.

Mediator ditunjuk oleh para pihak (secara langsung maupun melalui lembaga mediasi), dan berkewajiban untuk melaksanakan tugas dan fungsinya berdasarkan pada kehendak dan kemauan para pihak.

Walaupun demikian, ada suatu pola umum yang dapat diikuti pada umumnya dijalankan oleh mediator dalam rangka penyelesaian sengketa para pihak. Sebagai suatu pihak diluar perkara, yang tidak memilki kewenangan memaksa, mediator berkewajiban untuk bertemu atau mempertemukan para pihak yang bersengketa guna mencari masukan mengenai pokok persoalan yang dipersengketakan oleh para pihak (Ariani, 2012). Berdasrkan pada informasi yang diperolaeh, baru kemudian mediator dapat menentukan duduk perkara, kekurangan dan kelebihan dari masing-masing pihak yang bersengketa, dan selanjutnya mencoba menyusun proposal penyelesaian, dan kemudian dikomunikasikan kepada para pihak secara langsung.

Untuk menangani perkara perdata yang masuk ke Pengadilan, telah dikeluarkan Peraturan Mahkamah Agung (PERMA) No. 2 tahun 2003, yang telah direvisi dan diganti oleh PERMA No. 1 tahun 2008 tentang prosedur mediasi di Pengadilan. PERMA ini dimaksudkan untuk memberi akses yang lebih besar kepada para pihak dalam rangka menemukan penyelesaian secara damai yang memuaskan dan memenuhi rasa keadilan (Mardhiah, 2011).

Dalam penelitian ini penyusun menjadikan Pengadilan Agama Kelas 1A Watampone sebagai subjek penelitian dengan alasan Pengadilan Agama Kelas 1A Watampone terletak di Kota besar yang setiap tahunnyaangka perceraian terus mengalami peningkatan, sehingga dengan penelitian ini dapat diketahui sejauh mana peran dan fungsi lembaga mediasi di Pengadilan Agama Kelas ıAWatampone berperan aktif dalam menekan jumlah angka perceraian. 
Secara umum mediasi dapat diterapkan oleh semua lembaga peradilan baik tingkat pertama, tingkat banding maupun kasasi dan Penijauan Kembali (PK) tidak terbatas hanya di Pengadilan Agama., namun penulis mengemukakan di Pengadilan Agama terkaiat perkaraperkara cerai gugat serta cerai talak. Akan tetapi, dalam prakteknya, biasanya muncul persoalan-persoalan (Problem), baik yang disebabkan oleh pihak tergugat dan penggugat, maupun hambatan-hambatan lain dari pihak pengadilan.

\section{METODE PENELITIAN}

Dalam penelitian ini peneliti menggunakan jenis penelitian bercorak Field research (penelitian lapangan), yaitu data-data yang diperoleh berdasarkan survai lapangan, yang dilakukan dengan cara menghimpun informasi-informasi melalui wawancara mendalam (indepth interview) terhadap sejumlah responden dari beberapa hakim mediator di lingkungan Pengadilan Agama Kelas 1A Watampone. Adapun lokasi penelitian di Pengadilan Agama Kelas 1A Watampone karena pengadilan tersebut mempunyai kewenangan untuk menangani perkara perceraian yang terlebih dahulu harus melewati tahap mediasi. Selainitu, Pengadilan Agama Kelas 1 A Watampone berada di Kota besar, yang mana pada setiap tahunnya angka perceraian terus mengalami peningkatan, sehingga dengan penelitian ini dapat diketahui sejauh mana peran dan fungsi lembaga mediasi di Pengadilan Agama Kelas 1A Watampone berperan aktif dalam menekan jumlah angka perceraian tersebut.

\section{PEMBAHASAN}

\section{A. Efektivitas Mediasi Terhadap Perkara Perceraian di Pengadilan Agama Kelas 1A Watampone}

Berdasarkan teori efektivitas hukum yang dikemukakan oleh Soerjono Soekanto, efektif tidaknya suatu hokum ditentukan oleh 5 (lima) faktor. Faktor-factor tersebut mempunyai arti netral, sehingga dampak positif atau negatinya terletak pada isi faktor-faktor tersebut. Faktor pertama adalah factor hukumnya sendiri, yakni Undang-undang yang dalam penelitian ini adalah Undang-undang Nomor 1 tahun 2016 Tentang Prosedur Mediasi di Pengadilan. Yang kedua adalah factor penegak hokum yakni para pegawai hokum pengadilan di lingkungan Pengadilan Agama Kelas 1A Watampone. Ketiga adalah factor sarana atau fasilitas yang mendukung penegakan hukum, karena tanpa adanya sarana atau fasilitas tertentu, maka tidak mungkin penegakan hokum akan berlangsung dengan lancar. Yang keempat adalah masyarakat, yakni lingkungan dimana hokum tersebut berlaku atau diterapkan. Dan yang kelima adalah factor kebudayaan yang pada dasarnya mencakup nilai-nilai yang mendasari hukum yang berlaku, nilai-nilai yang merupakan konsepsi-konsepsi abstrak mengenai apa yang dianggap baik sehingga ditaati dan apa yang dianggap buruk sehingga tidak ditaati.

Demikianlah 5 (lima) factor keberhasilan mediasi yang dijadikan sebagai alat ukur penelitian ini, dan berikut adalah penguraian mengenai analisa efektivitas mediasi: 


\section{5 | Kalabbirang Law Journal, 2 (1): 1-13.}

1. Tinjauan Yuridis

Tinjauan Yuridis Perma No. 1 Tahun 2016. PERMA Nomor 1 Tahun 2016 Tentang Prosedur Mediasi di Pengadilan merupakan salah satu faktor yang mempengaruhi efektivitas pelaksanaan mediasi di Pengadilan.

Dengan ditetapkannya Peraturan Mahkamah Agung Republik Indonesia (PERMA) Nomor 1 Tahun 2016 tentang Prosedur Mediasi di Pengadilan, telah terjadi perubahan fundamental dalam praktek peradilan di Indonesia Mediasi sebagai upaya untuk mendamaikan pihakpihak yang berperkara bukan hanya penting, tetapi harus dilakukan sebelum perkaranya diperiksa. Upaya perdamaian bukan hanya formalitas, tetapi harus dilakukan dengan sungguh-sungguh agar permasalahan antara kedua belah pihak dapat menemui titik temu.Dengan Perma No.1 Tahun 2016 ini, mediasi wajib ditempuh sebagai salah satu tahapan dalam proses berperkara dilingkungan peradilan umum dan peradilan agama. Pelaksanaan mediasi disini harus dilihat sebagai pelaksanaan dari ketentuan HIR dan RBG, sehingga kalau prosedur PERMA tidak diikuti berarti merupakan RBG. Sanksi hukumnya adalah pemeriksaan demi hokum atau Nietigbaar, artinya dianggap tidak pernah ada pemeriksaan dan putusan perkara. Setiap pemeriksaan perkara perdata di pengadilan harus diupayakan perdamaian dan mediasi sendiri merupakan kepanjangan upaya perdamaian. Mediasi akan menjembatani para pihak dalam menyelesaikan masalah yang buntu agar mencapai/memperoleh solusi terbaik bagi mereka. PERMA Nomor 1 Tahun 2016 Tentang Prosedur Mediasi di Pengadilan memiliki kekuatan hukum yang mengikat dan ada daya paksa bagi masyarakat. Landasan yuridis PERMA Nomor 1 Tahun 2016 adalah peraturan perundang-undangan, sehingga diakui keberadaannya dan mempunyai kekuatan hokum mengikat. PERMA merupakan pelengkap peraturan perundang-undangan yang telahada. Sehingga bertujuan mengisi kekosongan hukum.Penerbitan PERMA tidak bertentangan dengan hukum dan aturan perundangundangan.

Berdasarkan wawancara dengan Bapak Drs.Muslimin mengatakan bahwa disetiap kasus perceraian di Pengadilan Agama Kelas iA Watampone melalui sebuah mediasi karena dengan mediasi dapat menghasilkan sebuah kesepakatan apakah berdamai atau tidak sehingga masalah yang terjadi dapat terselesaikan.

\section{Kualifikasi Mediator}

Keberhasilan mediasi juga bisa di lihat dari efektivitas pelaksanaan mediasi yang bertumpu pada profesionalitas hakim mediator dalam melaksanakan proses mediasi (keahlian di bidang hukum formil dan materiil, dan juga keahlian di bidang psikologis), hakim mediator harus bersertifikat, adanya substansi hukum atau peraturan yang jelas dan terperinci untuk mengupayakan damai dengan sungguh-sungguh.

Seluruh hakim mediator harus memiliki sertifikat mediator untuk meyakinkan bahwa mediator tersebut mempunyai ketrampilan dan kemampuan untuk menyelesaikan perkara dengan teknik yang baik dan efektif serta mediasi dapat berhasil. Seluruh hakim mediator di Pengadilan Agama Kelas 1A Watampone bersertifikat mediator sehingga tingkat keberhasilan 
akan mediasi dapat meningkat. Hakim yang melaksanakan fungsi mediator dan telah bersertifikat cenderung memiliki tingkat keberhasilan yang lebih disbandingkan dengan hakim yang melaksanakan fungsi mediator tidak memiliki sertifikat. Namun, pelatihan mediator bagi para hakim yang menjalankan fungsi mediator bukan satu-satunya jalan keberhasilan mediasi di pengadilan, karena tingkat keberhasilan mungkin tidak terpaut jauh dengan hakim yang telah bersertifikat. Hakim yang telah bersertifikat pun belum tentu mampu menggapai angka keberhasilan mediasi yang cukup tinggi, tetapi pelatihan harus tetap diberikan kepada semua hakim yang mejalankan fungsi mediator.

Berdasarkan wawancara dengan Bapak Drs. Ramli Kamil mengatakan bahwa semua Hakim yang ada di Pengadilan Agama Watampone sudah melalui beberapa tahap sehingga memiliki sertifikat mediasi dan dapat melakukan mediasi.

\section{Fasilitas dan Sarana}

Ruang mediasi di Pengadilan Agama Kelas 1A Watampone hanya ada 1 (satu) ruang yang berukuran sekitar5 meterx 4 meter, di dalamnya hanya ada 1(satu) meja dan 3 (tiga) kursi. Dalam ruang tersebut dapat dilakukan 1 (satu) kali proses mediasi.

Fasilitas ruang mediasi masih kurang ideal bagi proses mediasi. Faktor-faktor yang menyebabkan tidak idealnya ruang mediasi adalah :

a. Tidak adanya keseimbangan antara ruangan dan laju jumlah perkara yang masuk di Pengadilan Agama Kelas 1A Watampone guna melakukan proses mediasi bagi para pihak dikarenakan ruangan yang tersedia hanya 1 (satu), sehingga para pihak seringkali terlihatmengantri.

b. Tidak tersedianya ruang untuk kaukus. Padahal proses kaukus adalah sebagai alternatif yang dapat diupayakan oleh mediator untuk proses perdamaian para pihak.

Fasilitas pendukung yang kurang, seperti alat peraga, proyektor dan baiknya diupayakan tersedianya Air Conditioner (AC) yang dapat menjadikan ruangan mediasi terasa sejuk.

\section{Kepatuhan Masyarakat}

Mengenai kepatuhan masyarakat, penulis memberikan catatan mengenai perilaku dan sikap para pihakselama proses mediasi yang mempengaruhi kepatuhan mereka dalam menjalani proses mediasi, yakni sebagai berikut:

a. Sering kali salah satu pihak atau keduanya merasa paling benar. Mediator kesulitan mendalami masalah karena sikap mereka yang tidak kooperatif selama proses mediasi. Sikap egois sering muncul pula pada diri para pihak.

b. Sebelum para pihak memasuki pemeriksaan perkara di persidangan, sering kali mereka sudah bersepakat untuk memutuskan ikatan perkawinan. Sehingga saat dilakukan mediasi, sangat sulit bahkan gagal untuk didamaikan.

c. Komunikasi para pihak sudah lama terputus. Konflik yang telah berlarut-larut menyebabkan kedua belah pihak sudah tidak ada iktikad untukdamai. 


\section{7 | Kalabbirang Law Journal, 2 (1): 1-13.}

Para pihakada juga yang kooperatif, namun sikap tersebut mereka lakukan agar proses mediasi cepat selesai hingga dapat dilanjutkan ke proses persidangan selanjutnya. Mereka mengikuti mediasi hanya sebagai formalitas.

Berdasarkan wawancara dengan Sairah bahwa proses mediasi di Pengadilan Agama Watampone bahwa sikap dan perilaku dalam tahap mediasi sangat berpengaruh karena kedua belah pihak saling memahami satu sama lain hal itu mempengaruhi mediasi.

\section{Kebudayaan}

Banyak hal yang menyebabkan terjadinya perceraian pada Peradilan Agama di tingkat pertama. Pertama adalah moral. Persoalan moral pun memberikan antil untuk memantik krisis keharmonisan rumah tangga. Modusnya mengambil tiga bentuk, yakni suami melakukan poligami tidak sesuai dengan aturan, krisis akhlak, dan cemburu yang berlebihan. Kedua, meninggalkan kewajiban. Ini disebabkan salah satu pihak tidak bertanggung jawabakan kewajibannya selama menjalani ikatan perkawinan, seperti nafkah baik lahir maupun batin. Ketiga, kawin dibawah umur. Biasanya terjadi pada pihak istri yang sejarah perkawinannya dipaksa oleh kedua orang tuanya yang kemudian hari banyak menimbulkan ketidakharmonisan diantara pasangan suami istri. Keempat, dihukum. Salah satu pihak dijatuhi hokum pidana oleh pengadilan. Kelima, cacat biologis. Salah satu pihak memiliki cacat fisik yang tidak dapat disembuhkan, sehingga menyebabkan tidak dapat melaksanakan kewajiban. Keenam, terus menerus berselisih. Perselisihan dalam perkawinan yang berujung pada peristiwa perceraian ini dapat disebabkan ketidakharmonisan pribadi, gangguan pihak ketiga. Ketujuh, adalah faktor-faktor lainnya.

Faktor penyebab banyaknya angka perceraian serta tidak efektifnya pelaksanaan mediasi dalam perkara perceraian pada Pengadilan Agama Kelas 1A Watampone menurut penulis dapat dipengaruhi oleh hal-hal berikut :

a. Persepsi masyarakat muslim khususnya di Watampone tentang perceraian bahwa Islam mengajarkan talak adalah perbuatan halal walaupun dibenci Allah. Terlebih apabila perceraian adalah satu-satunya jalan keluar dari konflik rumah tangga yang akan membahayakan salah satu pihak atau keduanya, maka tentulah masyarakat memilih perceraian sebagai pilihan terakhir

b. Semakin meningkatnya kualitas pendidikan masyarakat terutama perempuan. Maka istri yang berpendidikan tinggi jika diceraikan oleh suaminya tidak lagi khawatir akan nafkah dirinya dan anak-anaknya. Dengan bekal pendidikan yang dimilikinya, seorang wanita dapat mencari pekerjaan untuk pemenuhan kebutuhannya.

c. Penempatan pelaksanaan mediasi di Pengadilan Agama tidak tepat. Faktor inilah yang paling mendasar tidak efektifnya mediasi di Pengadilan Agama. Penulis berpendapat bahwa pelaksanaan mediasi harus dilakukan diluar Pengadilan Agama oleh pihak keluarga suami-isteri yang diangkat (ditugaskan) oleh hakim (ulul amri), yang dipandang cukup banyak mengetahui hal-ihwal pasangan dan problematika di antara mereka untuk 
mencari kemaslahatan dan bermusyawarah secara proaktif guna menemukan akar permasalahan sekaligus mengupayakan solusi jalan damai bagi keduanya.

Oleh karena keluarga mempunyai pengaruh yang sangat besar secara psikologis dari pada orang lain, khususnya dalam mengungkap rahasia-rahasia yang rumit dan pelik, karena sebab-sebab konflik adakalanya bersifat rahasia, yang tidak mungkin diungkapkan kepada orang lain.

Jika kemudian solusi jalan damai tersebut ditolak dan menemui jalan buntu, maka dengan demikian nyatalah bahwa telah terjadi syikak (perpecahan) pada pasangan suami isteri tersebut, maka amanah tugas dikembalikan pada sang hakim untuk mengambil keputusan bagi pasangan tersebut dengan tetap menjadikan hasil penyelidikan dan pendapat para hakam sebagai bahan pertimbangan dalam memutuskan perkara tersebut

Demikian lima faktor keberhasilan mediasi yang dijadikan penulis sebagai alat ukur penelitian ini. Adapun teori efektivitas ini bersifat netral, maka dikatakan efektif apabila berhasil dijalankan dan dikatakan tidak efektif apabila tidak dijalankan. Demikianlah teori efektivitas hukum hasil pemikiran Soerjono Soekanto.

Sebagai permasalahan utama dalam penelitian ini penulis akan menjelaskan tentang efektivitas mediasi dalam penyelesaian perkara perceraian yang terjadi di Pengadilan Agama Kelas ${ }_{1}$ A Watampone. Dalam hal ini peneliti akan menyampaikan komentar para Hakim Mediator sebagai informan utama.

Drs. Kalimang, M.H dalam komentarnya mengatakan:

"Jadi itu gini, menurut saya mediasi disini di PA Watampone masih kurang begitu efektif. Coba sampean lihat di rekap jumlah perkara perceraian yang masuk setiap bulannya rata-rata hampir lebih dari 100 kasus, kalau setahun sudah berapa kasus. Lha dari sekian banyak kasus itu hanya sedikit sekali yang dapat di damaikan, tidak ada 10 persen yang sukses di mediasi.Kenapa seperti ini?Ya soalnya orangnya sudah ndak punya itikad untuk berbaikan seperti semula. Rata- rata mereka itu sudah berselisih sejak lama dengan suami atau istrinya, entah masalah nafkah, kekerasan, ada juga yang gara-gara kawin muda, bahkan ada juga garagara nafkah batin yang tak terpenuhi sampai menggugat cerai, itupun gagal dimediasi, ya emang yang paling penting itu dari orangnya, dari pribadi masing-masing “

Hal yang berbeda dikatakan oleh Dra.Husniati, S.H. dalam komentarnya sebagai berikut:

“Menurut saya seperti ini Nak, jadi seperti dalam Peraturan Pemerintah Tahun 20o8, mediasi menjadi hal wajib bagi siapa saja yang berperkara di Pengadilan gak peduli Pengadilan Negeri atau Agama, yang jelas itu wajib. Tapi fakta di lapangan tidak seperti yang diharapkan terutama dalam hal perceraian. Kalau efektif atau tidaknya mediasi menurut saya ya efektif efektif saja, soalnya meski yang berhasil dimediasi itu cuma sedikit tapi masih ada yang berhasil kan, meski jumlahnya gak seberapa. Harusnya dalam masalah ini lebih sering diadakan pelatihan mediator bagi hakim-hakim yang gak punya sertifikat mediator, mungkin dengan itu mediasi akan lebih efektif lagi terutama dalam hal keberhasilannya 


\section{9 | Kalabbirang Law Journal, 2 (1): 1-13.}

Peranan mediator dalam mediasi juga merupakan hal penting yang dapat mempengaruhi tingkat keberhasilan mediasi. Mediator yang pandai mengolah konflik dan berkomunikasi dapat mengupayakan adanya titik temu antara para pihak akan mudah mendorong terjadinya perdamaian. Dengan kata lain kemampuan seorang mediator berpengaruh besar terhadap keberhasilan mediasi. Kejelian merupakan hal yang sangat dibutuhkan dalam mengungkap dan menyelesaikan problem dengan jalan mediasi sehingga para pihak berperkara mendapatkan solusi yang dapat diterima kedua belah pihak dengan damai dan baik.

Untuk lebih menguatkan hasil penelitian ini peneliti juga mendapatkan informasi dari pihak berperkara yang enjalani proses mediasi di Pengadilan Agama Kelas 1A Watampone. Mereka adalah Ambo Dai warga Kec.Lapri Watampone dan Ahmad warga Kec.Salomekko Watampone yang berhasil peneliti wawancarai sebagai informan penguat dari apa yang disampaikan oleh hakim mediator.

Dalam hal ini Ambo Dai mengatakan tentang proses mediasi: “Mediatornya sabar Dinda, jadi saya ngrasa nyaman dengan proses mediasinya meski ngantri sekian lama, saya cukup puas dengan cara mereka menangani kasus- kasus yang segini banyaknya, terutama kawin cerai. Hakimnya serius tapi santai Dek, alhamdulillah mungkin cerai emg udah jadi jalan terbaik buat saya Dek.

Hal serupa juga disampaikan oleh Syarifa, Ia mengatakan tentang proses mediasi sebagai berikut :

"Hakim-hakim yang jadi mediatornya memfasilitasi kita selaku yg dimediasi dengan baik Dek, Cuma kelihatan sekali kalau mereka berusaha mempercepat proses mediasi secepat mungkin, tapi mereka tetap totalitas dalam menjalankan proses mediasi tersebut, totalitas disini yang saya maksudkan, mereka tetap mengusahakan yg terbaik bagi kami. Mungkin mereka mempercepat proses ya soalnya yg dimediasi kn bukan Cuma kami, tapi masih banyak yang antri dibelakang itu.

Dari Wawancara kepada Pasangan termediasi diatas peneliti menarik benang merah bahwasanya mediator sengat erat kaitannya dengan berhasil atau tidaknya proses mediasi. Keseungguhan hakim menjadi proritas utama dalam perdamaian yang di upayakan oleh mediator hasil akhirnya tetap ada di tangan pihak yang berperkara, kembali kepada yang di mediasi

\section{B. Tingkat Keberhasilan Mediasi dalam perkara perceraian di pengadilan Agama Kelas 1A Watampone}

Untuk mengetahui tingkat keberhasilan mediasi dalam perkara perceraian di Pengadilan Agama Kelas 1A Watampone, penulis menggunakan Laporan Pemberdayaan Lembaga Perdamaian Pengadilan Agama Kelas 1A Watampone Tahun 2017 sampai dengan tahun 2019. Data laporan tersebut merupakan laporan tahunan di Pengadilan Agama Kelas 1A Watampone. Didalamnya dapat diketahui perkara yang masuk kelembaga perdamaian dan 
dilaporkan hasil mediasi yang berhasil maupun yang tidak berhasil. Sehingga dengan laporan ini, dapat diketahu idengan mudah jumlah perkara yang dimediasi dan hasilnya.

Berikut penulis rangkum laporan pemberdayaan lembaga perdamaian perkara perceraian di Pengadilan Agama Kelas 1A Watampone, sebagaimana tertera pada tabel di bawah ini:

Tabelı. Laporan Registrasi Mediasi Pengadilan Agama Kelas 1 A Watampone Tahun 2017, 2018, dan 2019.

\begin{tabular}{|c|c|c|c|c|c|}
\hline \multirow{2}{*}{ No } & \multirow{2}{*}{ Tahun } & \multicolumn{2}{|c|}{ Jumlah Perkara } & \multirow{2}{*}{ Berhasil } & \multirow{2}{*}{ Persentase } \\
\hline & & Cerai Gugat & Cerai Talak & & \\
\hline 1 & 2017 & 878 & 349 & 1 & 0,09 \\
\hline 2 & 2018 & 1109 & 285 & 4 & 0,29 \\
\hline 3 & 2019 & 1069 & 306 & 5 & 0,36 \\
\hline
\end{tabular}

Sumber data : Kepaniteraan Pengadilan Agama Watampone.

Dari Tabel di atas Bahwasanya Perkara Perceraian Di pengadilan Agama Kelas 1A Watampone Pada Tahun 2017 Jumlah Perkara Cerai gugat Maupun Cerai Talak Berjumlah 1,227 Perkara, yang berhasil di mediasi berjumlah 1 Perkara Bila di Persentasekan Sekitar o,o9\%.

Pada Tahun 2018 Dari Tabel diatas Bahwasanya perceraian di pengadilan agama kelas ${ }_{1} \mathrm{~A}$ watampone mengalami Peningkatan Jumlah perkara cerai gugat maupun cerai talak yang berjumlah 1,394 kasus, yang berhasil di mediasi berjumlah 4 perkara bila di persentasekan sekitar $0,29 \%$.

Dan Pada Tahun 2019 Dari table di atas Bahwasanya perceraian di pengadilan agama kelas 1A watampone Mengalami Penurunan dari Tahun 2018 Yang Jumlah perkara Cerai gugat maupun cerai Talak yang berjumlah 1,375 Kasus, dan Yang berhasil di mediasi berjumlah 5 Perkara Bila Di persentasekan Sekitar o,36\%.

Dari Tabel diatas dapat di pahami Bahwa mediasi Tidak terlalu efektif dalam hal menyelesaikan perselisihan antara suami istri, yakni dalam hal perceraian, Terbukti dari tingkat keberhasilannya yang tidak mencapai 10\% Setiap tahunnya Mulai dari tahun 2017 sampai dengan tahun 2019.

\section{Faktor Mempengaruhi Hakim Mediator Terhadap Keberhasilan Mediasi}

Pada bagian ini penulis akan menjelaskan mengenai pengaruh-pengaruh seorang Hakim Mediator. Hakim Mediator yang dimaksudkan disini adalah seorang Hakim yang juga bertindak sebagai seorang Mediator.Mengenai apa saja yang menyebabkan rendahnya keberhasilan mediasi ditinjau dari segi Hakim Mediator, penulis mewawancarai Drs. 
Kalimang, selaku dewan hakim, juga berperan sebagai mediator. Dalam hal ini beliau menyampaikan dalam komentarnya:

“ Pada dasarnya Mediator selalu berusaha menengahi proses mediasi, jadi tidak boleh berat sebelah, ya memang tidak boleh memihak karena dapat merugikan salah satu pihak yang dimediasi. Tapi selain sebagai mediator saya juga jadi Hakim yang mempunyai tanggung jawab persidangan yang harus diselesaikan. Jadi, mediasi ya jadi tanggung jawab kedua saya, sesuai dengan instruksi dari pimpinan.

"Belum lagi hal yang paling sering itu salah satu pihak atau keduanya merasa paling benar.jadi Mediator kesulitan mendalami masalah, karena sikap mereka yang tidak bersahabat selama proses mediasi. Lebih bersifat egois adalah hal lumrah yang sering muncul pada diri para pihak.Sebelum para pihak memasuki pemeriksaan perkara di persidangan, biasanya mereka sudah sepakat untuk memutuskan ikatan perkawinan apapun yang terjadi.Sehingga saat dilakukan mediasi, sangat sulit mencapai perdamaian. Dengan kata lain mediasi telah gagal.

Ditanya tentang pengaruh Hakim Mediator, Muslimin memberikan komentarnya sebagai berikut:

"Kalau kita bicara masalah pengaruh Hakim Mediator dalam sebuah proses mediasi, pasti mempunyai pengaruh yang cukup besar, apalagi jika mediator tersebut adalah anggota dewan hakim, yang sampean tau sendiri lah berapa banyaknya kasus gugatan yang harus dipersidangkan oleh hakim. Disamping itu hakim mediator juga punya kesibukannya sendiri di luar pengadilan, keluarga misalnya.

"Faktor psikologi mediator sendiri secara tak langsung juga dapat mempengaruhi hasil akhir dari mediasi.Sekali lagi seorang hakim tidak hanya mempunyai tugas memediasi perkara tapi juga banyak hal lainnya yang harus diselesaikan. Tapi tetap dalam proses mediasi yang berlangsung, kami berusaha semaksimal mungkin untuk memberikan solusi yang terbaik, sehingga perkara dapat diselesaikan dengan baik.”

Mengenai pengaruh Hakim mediator terhadap keberhasilan mediasi Nurmiati, mengatakan:

“Menurut saya, hakim yang juga menjadi mediator tidak terlalu banyak mempengaruhi hasil akhir mediasi. Ya memang mempengaruhi tapi sedikit kemungkinannya. Dikarenakan dalam memediasi kita akan tetap berusaha mengoptimalkan semaksimal mungkin, tetapi dalam praktiknya, faktor emosional para pihak tidak dapat dikalahkan. Ya sebagai wasit kami hanya mengarahkan menuju kesepakatan final yang terbaik. Banyaknya kegagalan yang terjadi selama ini merupakan akibat dari perselisihan pihak berperkara sendiri.

"Kalau ditanya hubungannya dengan kesibukan lain seperti persidangan, atau hal-hal lain di luar pengadilan menurut saya tidak ada hubungannya. Waktu sidang ya sidang, waktu mediasi ya mediasi”

Berdasarkan hasil dari wawancara diatas peneliti berpendapat bahwa Hakim yang juga menjadi seorang mediator mempunyai pengaruh yang cukup besar terhadap tingkat keberhasilan mediasi. Dualisme fungsi Seorang hakim yang juga merangkap menjadi 
mediator berpengaruh pada psikologi hakim itu sendiri yang menjadikan tidak maksimalnya mediasi.Dengan sekian banyak perkara yang ditangani oleh Pengadilan Agama Watampone, dan juga permasalahan-permasalahan lain di luar Pengadilan yang menjadi tanggung jawab, adalah hal yang lumrah apabila hakim mediator sedikit terkendala dengan hal tersebut.

\section{KESIMPULAN}

Berdasarkan penjelasan yang diuraikan pada bab-bab sebelumnya, berkenaan dengan Efektifitas mediasi perceraian di Pengadilan Agama Kelas 1A Watampone, dapat disimpulkan sebagai berikut: Pertama, Efektivitas Mediasi Perceraian di Pengadilan Agama Kelas 1A Watampone Belum Efektif. Kedua, Faktor-Faktor Yang Berpengaruh Terhadap Efektivitas Mediasi Perceraian Di Pengadilan Agama Kelas 1A Watampone, Adalah Faktor Hukum Sudah Cukup Baik, Faktor Stuktur Hukum Perlu Pemberdayaan, Faktor Budaya Masyrakat Belum Mendukung

\section{SARAN}

Adapun saran-saran yang ditujukan kepada pihak-pihak yang terkait sebagai berikut:

1. Hendaknya Pengadilan Agama memberikan tes dan pelatihan kemampuan dalam memberikan mediasi, agar hakim mediator dapat menyusun strategi-strategi yang tepat supaya para pihak mengurungkan niatnya untuk bercerai.

2 Untuk perkara perceraian dimana kedua pihak sama-sama menginginkan perceraian,setelah di mediasimaka hakim akan lebih baik untuk melanjutkan proses persidangan tanpa harus melalui proses mediasi hal ini untuk mewujudkan penyelesaian sengketa yang lebih cepat dan murah (konsideran PERMA

\section{DAFTAR PUSTAKA}

Abbas, I., Bunga, M., Salmawati, S., Puji, N. P., \& Djanggih, H. (2018). Hak Penguasaan Istri terhadap Mahar Sompa Perkawinan Adat Bugis Makassar (Kajian Putusan PA Bulukumba Nomor 25/Pdt. P/2011/PABlk). Kanun: Jurnal Ilmu Hukum, 20(2), 203-218.

Ariani, N. V. (2012). Alternatif penyelesaian sengketa bisnis di luar pengadilan. Jurnal Rechts Vinding: Media Pembinaan Hukum Nasional, 1(2), 277-294.

Handayani, F., \& Syafliwar, S. (2017). Implementasi Mediasi dalam Penyelesaian Perkara Perceraian di Pengadilan Agama. Jurnal Al Himayah, 1(2), 227-250.

Komarudin, P. (2014). Penyelesaian Sengketa Ekonomi Syari'ah Melalui Jalur Non Ligitasi. Al Iqtishadiyah Jurnal Ekonomi Syariah dan Hukum Ekonomi Syariah, 1(1), 87-105.

Korah, R. S. (2013). Mediasi merupakan salah satu Alternatif Penyelesaian Masalah dalam Sengketa Perdagangan Internasional. Jurnal Hukum Unsrat, 21(3), 872.

Kusumaningrum, A., \& Yunanto, B. R. (2017). Efektivitas Mediasi dalam Perkara Perceraian di Pengadilan Negeri Semarang. Diponegoro Law Journal, 6(1), 1-10. 
13 | Kalabbirang Law Journal, 2 (1): 1-13.

Lestari, R. (2013). Perbandingan Hukum Penyelesaian Sengketa Secara Mediasi di Pengadilan dan Di Luar Pengadilan di Indonesia. Jurnal Ilmu Hukum, 4(2), 217-237.

Mardhiah, A. (2011). Penyelesaian Sengketa melalui Mediasi Berdasarkan Perma No. 1/2008. Kanun: Jurnal Ilmu Hukum, 13(1), 153-169.

Nurhadi, M. (2014). Problema Hakim dalam Menangani Mediasi Perceraian di Pengadilan Agama Kota Palopo (Suatu Tinjauan Hukum Islam) (Doctoral dissertation, Universitas Islam Negeri Alauddin Makassar).

Saladin, T. (2017). Penerapan Mediasi Dalam Penyelesaian Perkara Di Pengadilan Agama. Mahkamah: Jurnal Kajian Hukum Islam, 2(2), 146-161.

Salamah, Y. Y. (2013). Urgensi Mediasi dalam Perkara Perceraian di Pengadilan Agama. AHKAM: Jurnal Ilmu Syariah, 13(1), 81-88.

Tamalawe, D. (2016). Efektivitas Mediasi sebagai Bagian dari Bentuk Pencegahan Perceraian Menurut Hukum Acara Perdata. Lex Crimen, 5(3), 22-29 